44. Podstawy pedagogiki chrześcijańskiej, Rocznik Wydziału Filozoficznego Towarzystwa Jezusowego w Krakowie 1991-1992, s 72 - 74.

45. Wyklady Jana Kormana na Katedrze Polityki Uniwersytetu Wileńskiego, Rocznik Wydziału Filozoficznego Towarzystwa Jezusowego w Krakowie 1991-1992, s. 267-275.
1993

46. Dzialalnośc jezuitów polskich na polu szkolnictwa (1565 - 1773), w: Jezuici a kultura polska, Kraków 1993, s. 243-259.

47. Zapis wykladów na katedrze polityki profesora Akademii Wileńskiej Jana Kormana, Horyzonty Wiary, 16 (1993), s. 70-77.

\title{
Historia wychowania w Wyższej Szkole Pedagogicznej w Rzeszowie
}

W bieżącym roku mija 12 lat od utworzenia Zakładu Historii Oświaty i Wychowania w Wyższej Szkole Pedagogicznej w Rzeszowie. Jednak początek działalności naukowej i dydaktycznej z zakresu historii wychowania jest związany z powstaniem Zakładu Andragogiki i Historii Wychowania (1981 r.) wchodzącego w skład Instytutu Pedagogiki i Psychologii, a od 1986 roku Instytutu Pedagogiki. Kierownikiem Zakładu był dr Andrzej Janczur. Wcześniej przedmiot ten był realizowany przez pracowników Katedry Pedagogiki, natomiast w zakresie badań naukowych dominowały prace indywidualne związane glównie $z$ uzyskaniem stopni naukowych. Dalsze zmiany organizacyjne, tj. powołanie Zakładu Historii Oświaty i Wychowania (1984 r.) przyczyniły się do rozwinięcia planowej działalności naukowej w tym zakresie. Kierownictwo Zakładu powierzono doc. dr hab. Andrzejowi Meissnerowi.

W ciagu 12 lat funkcjonowania Zakładu zespół historyków wychowania powiększał się, a jego pracownicy zdobywali stopni naukowe. Obecnie Zakład liczy 8 pracowników: 2 profesorów (A. Meissner, Czesław Majorek), 5 doktorów (Adam Horbowski, Czesław Płaza, Jerzy Potoczny, Kazimierz Szmyd i Władysława Szulakiewicz) oraz 1 magistra (Adam Krzanowski).

Do najważniejszych przedsięwzięć naukowych zrealizowanych w tym okresie należy zaliczyć organizację konferencji naukowych. Pierwsza z nich nt „Stan i potrzeby badań nad dziejami oświaty w Galicji" odbyła się w 1986 r. W 1989 r. ukazały się materiały pokonferencyjne pt. „Z dziejów oświaty w Galicji” pod red. A. Meissnera. Pracownicy Zakładu uczestniczyli także w międzynarodowej konferencji zorganizowanej w WSP w Rzeszowie nt „Galicja $\mathrm{i}$ jej dziedzictwo” (1992 r.), z której materiały zostały opublikowane w 3 tomie serii wydawniczej „Galicja i jej dziedzictwo" (zatytułowanym „Nauka i oświata”, Rzeszów 1995). Kolejną inicjatywą naukową była międzynarodowa sesja poświęcona „Myśli edukacyjnej w Galicji” (1995 r.). Również dorobek tej ostatniej zostanie wydany w odrębnym tomie pod redakcja A. Meissnera i Cz. Majorka.

Działalność badawcza pracowników Zakładu obejmuje dzieje oświaty i myśli pedagogicznej XIX i XX wieku. W obrębie jednak tak szeroko pojętej problematyki można wyodrębnić kilka szczegółowych zagadnień, będących przedmiotem zainteresowań poszczególnych badaczy. M.in. beda to:

- dzieje oświaty i myśli pedagogicznej w Galicji, nad którymi pracują A. Meissner, J. Potoczny, W. Szulakiewicz;

- historia oświaty dorosłych, która zajmują się A. Horbowski i J. Potoczny;

- dzieje organizacji oświatowych pozostajace w kręgu zainteresowań Cz. Płazy i A. Krzanowskiego;

- historia myśli pedagogicznej w II Rzeczypospolitej, nad którą skupiają się K. Szmyd i W. Szulakiewicz;

- oświata i szkolnictwo po II wojnie światowej, którq̨ badaja A. Meissner i A. Horbowski.

Dorobek naukowy w obrębie wymienionej problematyki badawczej jest znaczny i nie sposób go przedstawić w niniejszej publikacji. Warto jednak podkreślić, iż obecnie można 
mówić o ustaleniu się wspólnej problematyki badawczej Zakładu dotyczącej dziejów oświaty i myśli pedagogicznej w Galicji. Owocem prac nad tym tematem, oprócz wydawnictw zbiorowych sq publikacje indywidualne m.in. A. Meissnera: „Ksztalcenie nauczycieli w Galicji Srodkowej 1871-1918" (Rzeszów 1974), J. Potocznego: „Rozwój elementarnej oświaty dorosłych w Galicji doby autonomicznej 1867-1918" (Rzeszów 1988) i „Od alfabetyzacji do popularyzacji wiedzy. Ruch oświaty dorosłych w Galicji 1867-1919" (Rzeszów 1993) oraz W. Szulakiewicz "Władysław Seredyński. Studium z dziejów pedagogiki galicyjskiej" (Rzeszów 1995). Ponadto efektem pracy zbiorowej jest „Bibliografía dziejów oświaty i wychowania w Galicji 1772-1918", pod red. A. Meissnera i S. Możdżenia. W opracowaniu jest II część bibliografii do dziejów oświaty w Galicji.

Pracami nad ta problematyka kierują A. Meissner i Cz. Majorek, którzy sa redaktorami kolejnych tomów publikacji zbiorowych. Do druku zostały złożone min. prace: „Nauczyciele galicyjscy” (red. A. Meissner) oraz „Przedstawiciele galicyjskiej myśli pedagogicznej” (red. Cz. Majorek).

Rzeszowscy historycy wychowania współpracują $\mathrm{z}$ różnymi ośrodkami naukowymi w kraju, tj. Uniwersytetem Jagiellońskim, Poznańskim, Śląskim, Wrocławskim, IHN PAN w Warszawie i WSP w Krakowie. Współpraca ta dotyczy wspólnie realizowanych tematów badawczych.

$\mathbf{Z}$ działalnością naukową w pewien sposób łączy się działalność dydaktyczna pracowników Zakładu. W szczególności ma to związek z prowadzonymi seminariami $\mathrm{z}$ historii wychowania. Autorzy najlepszych prac powstających na seminariach zachęceni sq do dalszej pracy naukowej.

Przedstawiając historię wychowania w ośrodku rzeszowskim należy wspomnieć, iż w bieżacym roku akademickim zostaje uruchomione seminarium doktoranckie $\mathrm{z}$ historii wychowania.

Madyslawa Szulakiewicz

\section{KSIAZXI}

\section{Recenzje}

Rodzina a wychowanie. Ciąglość i zmienność na przestrzeni wieków, red. J. Jundzill, Bydgoszcz 1995, Instytut Wydawniczy „Swiadectwo", ss. 144

Zagadnienie wzajemnych relacji pomiędzy rodziną jako podstawowym środowiskiem oddziaływującym na rozwój emocjonalno-uczuciowy, moralny czy spoleczny dziecka, a procesem, w którym przemiany te zachodzą nie jest zbyt czesto podejmowane przez polskich badaczy. Znacznie częściej spotkać się można z rozlącznym podchodzeniem do tej problematyki: bądź to w aspekcie czysto historycznym, bądź psychologiczno-pedagogicznym. Pracownicy Katedry Historii Wychowania Wyżzzej Szkoły Pedagogicznej w Bydgoszczy starają się, skierowując uwage badaczy $z$ innych ośrodków naukowych kraju na interdyscyplinarny charakter badań nad rodziną, luke te uzupetnić. Taki cel ma, jak się wydaje, także zbiór "Rodzina a wychowanie. Ciagłość i zmienność na przestrzeni wieków”. Tytuł „Rodzina a wychowanie” suge- 